\title{
A Study on Relationship between Selected Independent Variables and Training Needs of Agricultural Extension Personnel in Arunachal Pradesh, India
}

\author{
Inne Lego ${ }^{1 *}$, R. Bordoloi ${ }^{2}$, Pankaj Kumar Meghwal ${ }^{3}$ and Moromi Buragohain ${ }^{4}$ \\ ${ }^{1}$ Agricultural Extension), CPGS, CAU, Umiam, Meghalaya, India \\ ${ }^{2}$ ATARI-III, ICAR RC for NE Region, Umiam, Meghalaya, India \\ ${ }^{3}$ Agricultural Extension, College of Agriculture, JAU, Junagadh, Gujarat, India \\ ${ }^{4}$ Agricultural Extension, AAU, Jorhat, Assam, India \\ *Corresponding author
}

\begin{tabular}{|c|}
\hline Keywords \\
\hline $\begin{array}{l}\text { Training needs, } \\
\text { Correlation, } \\
\text { Arunachal Pradesh, } \\
\text { Agriculture officer }\end{array}$ \\
\hline Article Info \\
\hline $\begin{array}{l}\text { Accepted: } \\
\text { 20 January } 2018 \\
\text { Available Online: } \\
\text { 10 February } 2018\end{array}$ \\
\hline
\end{tabular}

\section{Introduction}

Owana et al., (2010) defined training need as the skill, knowledge and attitude an individual requires in order to overcome problems as well as to avoid creating problem situation. In essence training needs is an essential resource, which will direct knowledge and 
skill towards production. Mishra (1990) defined training need for extension personnel in terms of gap between job requirement and job performance. According to Oakley and Garforth (1985), the success or failure of any extension program is dependent on effective performance by extension agents. However, effective performance of the extension personnel also depends on the personal and organizational profile of the extension agent. The Department of Agriculture, Arunachal Pradesh plays a very important role for the development of agriculture in the state. Various programme and activities are carried out by the Department of Agriculture through extension personnel to achieve the goals and visions set by them. The department along with well trained extension personnel needs favourable working environment for successful implementation of the programme.

\section{Materials and Methods}

The present study was conducted in the State, Arunachal Pradesh during 2015-2016. There are nineteen districts in the State, from which three districts viz., Papumpare, East Siang and West Siang were purposively selected based on the highest number of filled up post of agricultural officer. The organizational hierarchy of Agricultural officer in Arunachal Pradesh is District Agriculture Officer (DAO) - Sub Divisional Agriculture Officer (SDAO) - Agriculture Development Officer (ADO) Agriculture Research Officer (ARO). There are all total 64 officials in these three districts. So census method was followed for selecting the respondents. Out of the total 64 respondents, 60 responses were received. Hence, the total respondents of the study were 60. Primary data was collected by interview schedule and training items were consulted with the experts of state agriculture department. The training needs of agricultural/horticultural officers were worked out with the help of Training Need Quotient
(TNQ) developed by Sidhu (1973). The formula for calculating TNQ is as follow:

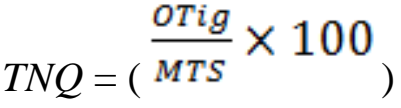

Where,

OTig = Sum of observed training scores of the items of the $i^{\text {th }}$ respondent

MTS = Sum of the maximum training scores attributed to the items rated by $i^{\text {th }}$ respondents TNQ = Training Need Quotient

The perceived training needs of respondent were the dependent variable of the study. There were ten independent variables selected for the study viz., age, gender, family size, educational level, family background, training exposure, mass media exposure, service length, job performance and organizational climate. A set of explicit hypotheses were formulated for testing in the present study. The hypotheses presented herein are the verbal statements of null hypothesis (Ho).

$\mathrm{H}_{0} 1$ : There is no relationship between age of the respondents and their training needs.

$\mathrm{H}_{0}$ 2: There is no relationship between gender of the respondents and their training needs.

$\mathrm{H}_{0} 3$ : There is no relationship between family size of the respondents and their training needs.

$\mathrm{H}_{0} 4$ : There is no relationship between educational level of the respondents and their training needs.

$\mathrm{H}_{0}$ 5: There is no relationship between family background of the respondents and their training needs.

$\mathrm{H}_{0} 6$ : There is no relationship between training exposure of the respondents and their training needs.

$\mathrm{H}_{0}$ 7: There is no relationship between mass media exposure of the respondents and their training needs.

$\mathrm{H}_{0}$ 8: There is no relationship between service length of the respondents and their training needs.

$\mathrm{H}_{0}$ 9: There is no relationship between job 
performance of the respondents and their training needs.

$\mathrm{H}_{0} 10$ : There is no relationship between organizational climate of the respondents and their training needs.

\section{Results and Discussion}

From the Table 1, it was found that majority of the respondents were male (83.30\%). Majority of the respondents were in between $35-50$ years of age $(88.30 \%)$ and B.Sc. Agri.graduate $(88.30 \%)$. Most of them had a family size of 5-7 (58.30\%) and were from a rural background (63.30\%). They had medium exposure to training $(61.70 \%)$ and mass media $(75.00 \%)$. Their service length ranges from 11-16 (50.00\%), had medium level of job performance (45.00\%) and they perceived a favourable organizational climate towards their department (65.00\%). It is observed from the Table 2 that 23.30 per cent of the respondents have low level of training needs, 63.30 per cent of the respondents have high level of training needs and only 13.40 per cent have medium level of training need.

Spearman Rank Correlation (Table 3) revealed that there was a significant and negative correlation between training need and age, training exposure, service length and job performance. However, correlation between training needs and family size, gender, educational level, family background, mass media exposure and organizational climate was non-significant.

Table.1 Profile of the respondents $(\mathrm{N}=60)$

\begin{tabular}{|c|c|c|c|c|c|c|}
\hline Sl. No. & $\begin{array}{l}\text { Independent } \\
\text { Variable }\end{array}$ & Category & Frequency & $\begin{array}{c}\text { Percentage } \\
(\%)\end{array}$ & Mean & SD \\
\hline \multirow[t]{3}{*}{1.} & \multirow[t]{3}{*}{ Age } & $\begin{array}{l}\text { Young age } \\
\text { (Below } 35 \text { years) }\end{array}$ & 5 & 8.30 & \multirow[t]{3}{*}{40.93} & \multirow[t]{3}{*}{5.13} \\
\hline & & $\begin{array}{l}\text { Middle age } \\
\text { (35-50 years) }\end{array}$ & 53 & 88.30 & & \\
\hline & & $\begin{array}{l}\text { Old age } \\
\text { (Above } 50 \text { years) }\end{array}$ & 2 & 3.40 & & \\
\hline \multirow[t]{2}{*}{2.} & \multirow[t]{2}{*}{ Gender } & Male & 50 & 83.30 & \multirow[t]{2}{*}{-} & \multirow[t]{2}{*}{-} \\
\hline & & Female & 10 & 16.70 & & \\
\hline \multirow[t]{3}{*}{3.} & \multirow[t]{3}{*}{ Family size } & $\begin{array}{l}\text { Small } \\
\text { (Below 4) }\end{array}$ & 20 & 33.30 & \multirow[t]{3}{*}{5.12} & \multirow[t]{3}{*}{1.60} \\
\hline & & $\begin{array}{l}\text { Medium } \\
(5-7)\end{array}$ & 35 & 58.30 & & \\
\hline & & $\begin{array}{l}\text { Large } \\
\text { (Above 7) }\end{array}$ & 5 & 8.40 & & \\
\hline \multirow[t]{3}{*}{4.} & \multirow{3}{*}{$\begin{array}{l}\text { Educational } \\
\text { level }\end{array}$} & B. Sc. & 53 & 88.30 & \multirow[t]{3}{*}{1.12} & \multirow[t]{3}{*}{0.32} \\
\hline & & M. Sc. & 7 & 11.70 & & \\
\hline & & Ph. D. & 0 & 0.00 & & \\
\hline \multirow[t]{3}{*}{5.} & \multirow{3}{*}{$\begin{array}{c}\text { Family } \\
\text { background }\end{array}$} & Rural & 38 & 63.30 & \multirow[t]{3}{*}{1.60} & \multirow[t]{3}{*}{0.85} \\
\hline & & Urban & 8 & 13.30 & & \\
\hline & & Semi-Urban & 14 & 23.40 & & \\
\hline 6 & $\begin{array}{l}\text { Training } \\
\text { exposure }\end{array}$ & $\begin{array}{l}\text { Less exposure } \\
(<10.25)\end{array}$ & 49 & 81.70 & 4.61 & 9.34 \\
\hline
\end{tabular}




\begin{tabular}{|c|c|c|c|c|c|c|}
\hline & & $\begin{array}{l}\text { Medium } \\
\text { exposure } \\
(10.25-20.80)\end{array}$ & 8 & 13.30 & & \\
\hline & & $\begin{array}{l}\text { High exposure } \\
(>20.80)\end{array}$ & 3 & 5.00 & & \\
\hline \multirow[t]{3}{*}{7.} & \multirow[t]{3}{*}{$\begin{array}{l}\text { Mass media } \\
\text { exposure }\end{array}$} & $\begin{array}{l}\text { Less exposure } \\
\text { (Below 24) }\end{array}$ & 7 & 11.70 & \multirow[t]{3}{*}{28.68} & \multirow[t]{3}{*}{4.53} \\
\hline & & $\begin{array}{l}\text { Medium } \\
\text { exposure } \\
(24-33)\end{array}$ & 45 & 75.00 & & \\
\hline & & $\begin{array}{l}\text { High exposure } \\
\text { (Above } 33 \text { ) }\end{array}$ & 8 & 13.30 & & \\
\hline \multirow[t]{3}{*}{8.} & \multirow[t]{3}{*}{ Service length } & $\begin{array}{l}\text { Less } \\
(<11 \text { years })\end{array}$ & 18 & 30.00 & \multirow[t]{3}{*}{12.40} & \multirow[t]{3}{*}{4.38} \\
\hline & & $\begin{array}{l}\text { Medium } \\
\text { (11-16 years) }\end{array}$ & 30 & 50.00 & & \\
\hline & & $\begin{array}{l}\text { Full } \\
(>16 \text { years) }\end{array}$ & 12 & 20.00 & & \\
\hline \multirow[t]{3}{*}{9.} & \multirow[t]{3}{*}{$\begin{array}{c}\text { Job } \\
\text { performance }\end{array}$} & $\begin{array}{l}\text { Low } \\
(<90)\end{array}$ & 12 & 20.00 & \multirow[t]{3}{*}{109.80} & \multirow[t]{3}{*}{25.63} \\
\hline & & $\begin{array}{l}\text { Medium } \\
(90-121)\end{array}$ & 27 & 45.00 & & \\
\hline & & $\begin{array}{l}\text { High } \\
(>121)\end{array}$ & 21 & 35.00 & & \\
\hline \multirow[t]{3}{*}{10.} & \multirow[t]{3}{*}{$\begin{array}{l}\text { Organizational } \\
\text { climate }\end{array}$} & $\begin{array}{l}\text { Less favourable } \\
(<13)\end{array}$ & 9.00 & 15.00 & \multirow[t]{3}{*}{15.40} & \multirow[t]{3}{*}{2.85} \\
\hline & & $\begin{array}{l}\text { Favourable } \\
(13-18)\end{array}$ & 39.00 & 65.00 & & \\
\hline & & $\begin{array}{l}\text { Most Favourable } \\
(>18)\end{array}$ & 12.00 & 20.00 & & \\
\hline
\end{tabular}

Table.2 Distribution of respondents according to their levels of training need $(\mathrm{n}=60)$

\begin{tabular}{|c|c|c|c|c|c|}
\hline Sl. No. & TNQ Categories & Frequency & Percentage (\%) & Mean & S.D \\
\hline $\mathbf{1}$ & $\begin{array}{c}\text { Low } \\
(<71.75)\end{array}$ & 14 & 23.30 & & \multirow{2}{*}{7.53} \\
\hline $\mathbf{2}$ & $\begin{array}{c}\text { Medium } \\
(71.75-80.98)\end{array}$ & 8 & 13.40 & 79.57 & \\
\hline $\mathbf{3}$ & $\begin{array}{c}\text { High } \\
(>80.98)\end{array}$ & 38 & 63.30 & & \\
\hline
\end{tabular}


Table.3 Correlation co-efficient of selected independent variables with training needs of extension personnel

\begin{tabular}{|c|l|c|c|}
\hline Sl. No. & \multicolumn{1}{|c|}{ Variables } & Correlation coefficient & P Value \\
\hline $\mathbf{1}$ & Age & -0.426 & $0.001^{* *}$ \\
\hline $\mathbf{2}$ & Gender & -0.068 & 0.604 \\
\hline $\mathbf{3}$ & Family size & 0.119 & 0.367 \\
\hline $\mathbf{4}$ & Educational level & -0.188 & 0.151 \\
\hline $\mathbf{5}$ & Family background & -0.099 & 0.450 \\
\hline $\mathbf{6}$ & Training exposure & -0.316 & $0.014^{*}$ \\
\hline $\mathbf{7}$ & Mass Media exposure & 0.053 & 0.685 \\
\hline $\mathbf{8}$ & Service length & -0.373 & $0.003^{* *}$ \\
\hline $\mathbf{9}$ & Job performance & -0.292 & $0.023^{*}$ \\
\hline $\mathbf{1 0}$ & Organizational climate & 0.040 & 0.759 \\
\hline
\end{tabular}

Note: ${ }^{* *}$ Indicates significant at 0.01 level

* Indicates Significant at 0.05 level

Table.4 Regression co-efficient of personal and organizational variables with training needs: Multiple regression

\begin{tabular}{|c|l|c|c|c|}
\hline Sl. No. & \multicolumn{1}{|c|}{ Variables } & t value & P Value & $\mathbf{R}^{2}$ \\
\hline $\mathbf{1}$ & Age & -1.574 & 0.058 & 0.449 \\
\hline $\mathbf{2}$ & Gender & 0.405 & 0.688 & \\
\hline $\mathbf{3}$ & Family size & 1.646 & 0.521 & \\
\hline $\mathbf{4}$ & Educational level & -1.200 & 0.236 & \\
\hline $\mathbf{5}$ & Family background & -1.563 & 0.125 \\
\hline $\mathbf{6}$ & Training exposure & -2.818 & $0.007^{* *}$ \\
\hline $\mathbf{7}$ & Mass media exposure & 1.144 & 0.258 \\
\hline $\mathbf{8}$ & Service length & -0.197 & 0.844 \\
\hline $\mathbf{9}$ & Job performance & -2.663 & $0.015^{*}$ & \\
\hline $\mathbf{1 0}$ & Organizational climate & 0.3152 & 0.884 & \\
\hline
\end{tabular}

Note $^{* *}$ indicates significant at 0.01 level *indicates significant at 0.05 level

Table.5 Regression coefficient of significant variables with training needs

\begin{tabular}{|c|l|}
\hline Sl. No. & Variables \\
\hline $\mathbf{1}$ & Training exposure \\
\hline $\mathbf{2}$ & Job performance \\
\hline
\end{tabular}

\begin{tabular}{|c|c|c|}
\hline \multicolumn{3}{|c|}{ Training exposure } \\
\hline t value & P value & $\mathbf{R}^{\mathbf{2}}$ \\
\hline-2.334 & $0.023^{*}$ & 0.157 \\
\hline-2.800 & $0.007^{* *}$ & \\
\hline
\end{tabular}

Note indicates significant at 0.01 level "indicates significant at 0.05 level 
In multiple regression, $\mathrm{R}^{2}$ value being 0.449 revealed that 44.90 per cent of the variation in the dependent variable is explained by the independent variables. The $\mathrm{R}^{2}$ value for the two significant variables job performance and training exposure being 0.157 suggests that the two variables training exposure and job performance jointly contributes to 15.70 per cent towards training needs (Table 4 and 5).

In conclusion, the variables age, service length, training exposure, and job performance should be considered while conducting training as these variables had significant correlation with the training needs of the respondents. Majority of the respondents were having high level of training needs. So adequate trainings should be provided to them by the state department of Agriculture and other training institutes. In multiple regression $\mathrm{R}^{2}$ being 0.449 revealed that 44.90 per cent of the variation in the dependent variable is explained by the independent variables. This shows that there are some hidden variables that explains the dependent variables in the study. Therefore, in future research programmes, other variables such as job satisfaction, level of knowledge, attitude towards agricultural profession etc. can be included for the study.

\section{References}

Mishra, D.C. (1990). New directions in Extension training. Directorate of Extension, Ministry of Agriculture, New Delhi.

Oakley, P. and Garforth, C. (1985). Guide to Extension Training. Rome, FAO.

Owana, N.P., Nyaka, N.A., Ehabe, E.E., Chanbon, P.B., and Bruneau, J. (2010). Assessment of training needs of rubber farmers in the Southwestern region of Cameroon. African J. Agric. Res. 5(17): 2326-2331.

Sidhu, B.S. (1973). Training needs of Agricultural masters in high school of Punjab. Summaries of extension research by post graduate students Vol.5. Department of Extension Education, PAU, Ludhiana.

\section{How to cite this article:}

Inne Lego, R. Bordoloi, Pankaj Kumar Meghwal and Moromi Buragohain. 2018. A Study on Relationship between Selected Independent Variables and Training Needs of Agricultural Extension Personnel in Arunachal Pradesh, India. Int.J.Curr.Microbiol.App.Sci. 7(02): 21392144. doi: https://doi.org/10.20546/ijcmas.2018.702.256 